\title{
A Literary Exposition of the Sources of Arabic Proverbs
}

\author{
Kazeem Adebayo Omofoyewa, $\mathrm{PhD}$ \\ (Department of Arabic and Islamic Studies/University of Ibadan, Nigeria)
}

\begin{abstract}
Proverbs excited the interest of the learned right from the inception of Arabic literature; historians and philologists vied with one another in collecting and explaining them. Indeed, to their works this generation owe most of the legendary and historical materials. This paper, therefore, examines the main sources of Arabic proverbs vis-à-vis the Qur'an, the hadith of the Prophet (PHOH) and the gamut of Arabic literature, with a view to establishing their literary worth and values. It argues that familiarity with the background of the proverbial expressions is very essential to comprehension since a number of them are so tied to the stories and tales behind them.
\end{abstract}

Keywords: Literary, exposition, sources, Arabic, proverbs.

\section{Introduction}

Arabic proverbs have numerous sources, some reaching back deep into history. As far back as 1107C.E, for instance, Abū al-Qāsim al-Zamakhsharī compiled a book of proverbs that were already old. He named it Al-Mustaqsā fì Amthāl al-Arab (The sought after Arabic proverbs) and included in its two volumes about 3,461 proverbs, along with notes on their sources and meanings. ${ }^{1}$ There is a sea of difference when this work is compared with the 'Durham proverbs' which are in some quarters thought to be the earlier known collection of Anglo-Saxon sayings. According to the Oxford Dictionary of English proverbs, this collection takes up a mere "three leaves... in the middle of an $11^{\text {th }}$ century hymnal.".

Prior to this time, an erudite scholar named Ahmad Ibn Muhammad al-Maydānī published the most comprehensive book containing 4,765 proverbs. ${ }^{3}$ The chapters are arranged in alphabetical order. The book was named Majma ' al-Amthāl (A collection of proverbs), and going by the author's note in its introduction, the work was based on 50 other books containing proverbs written by his predecessors. ${ }^{4}$

\section{The Qurān as a Source of Arabic Proverbs}

The richest source of Arabic proverbs is the Glorious Qurān. According to Fuad Rayess, " few verses (ayah) that have not been used as proverbs and to this day such proverbs permeate conversation, literature, speeches and even legal decisions". There seems to be no occurrence in human affairs to which some proverbs may not be applied. Perhaps this thought is expressed in the Glorious Qurān when Allah, the Almighty, says:

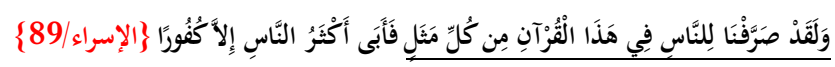

And We have explained to man, in this Qur'ān, every kind of similitude: Yet the greater parts of men refuse (to receive it) except with ingratitude.

(Qur'ān 17:89)

He also says:

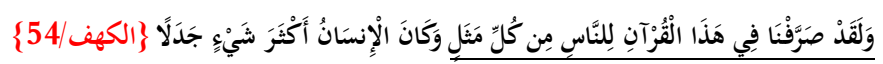

We have explained in detail in this Qurān, for the benefit of mankind, every kind of similitude: but man is, in most things, contentious.

(Qur'ān 18:54).

Similarly, He says:

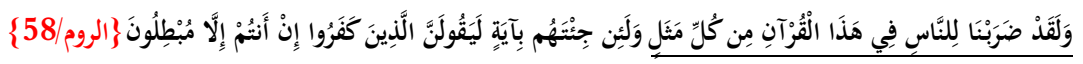

Verily We have propounded for men in this Qurān every kind of parable: but if thou bring to them any sign, the unbelievers are sure to say, "Ye do nothing but talk vanities," (Qur'ān 30:58).

He also states that:

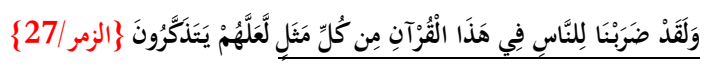


We have put forth for men, in this Qur'ān every kind of parable, in order that they may receive admonition.

(Qur'ān 39:27).

He states in another verse that:

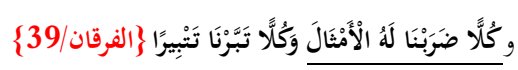

To each one We set forth parables and examples; and each one We broke to utter annihilation (for their sins).

And also:

(Qur'ān 25:39)

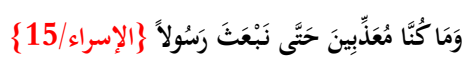

Nor would We visit our wrath until We had sent a messenger (to give warning).

(Qur'ān 17:15)

When these last two verses, (that is, Q25:39 \& Q17:15) are closely observed, it becomes obvious that proverbs are nothing but a synopsis of the Divine scriptures, particularly, the Glorious Qur'ān. No nation shall receive Divine punishment in as much as parables have not been made unto it, just like it shall not be punished unless a Divine revelation had been sent to it but refused to heed to it. ${ }^{6}$ It is thus evident that failure to heed to Allah's parables is tantamount to rejection of His revelation and this will eventually lead to the wrath of Allah, the Almighty, both in this world and the hereafter.

Al-Zarkashī also enumerates some derivable benefits of proverbial expressions used in the Glorious Qur'ān. According to him, these expressions serve as; التوعظ (al-Tadhkir) reminder, التذكير (al'z) admonition,

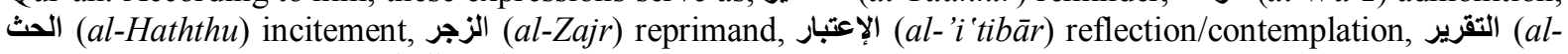
Takrìr) establishment, ترتيب المراد للعقل (Tartīb al-Murād li al-'aql) logical arrangement of thought for discernment. ${ }^{7}$

He reiterates further that these proverbial expressions express disparity in rewards, praises or blames, rewards and punishments as well as affirmations and abolitions of matters. ${ }^{8}$ He concludes saying that Allah's Divine Grace on mankind is evident in the compassionate manner with which $\mathrm{He}$, the Almighty, addresses humanity in His scripture: ${ }^{9}$

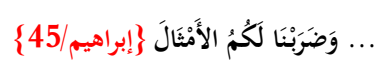

And We put forth (many) parables on your behalf!

(Qur'ān 14:45).

Proverbial expressions in the Glorious Qur'ān are basically divided into two parts. These are: (المثل الظاهر) "the apparent proverb" and (المثل الكامن) "the hidden proverb". The apparent one is that in which the word ( مثل mathal) is clearly stated. Example of this could be seen in a verse which Allah, the Almighty, revealed in respect of the hypocrites. It goes thus:

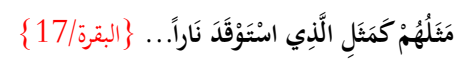

Their similitude is that of a man who kindled a fire...

(Qur'ān 2:17).

Besides, the apparent proverb is either shortened or elongated (a long story at times).

Moreover, the hidden proverb is that which the word " مثل - mathal" is not mentioned within, but there is evidence of its correlation with any proverb of the Arabs or the non-Arabs or even the one that has a universal application. That is, they are deduced from the popular ones. ${ }^{10}$ According to Hammūd, these kinds of proverbs are known by their meanings, not by their mere wordings. ${ }^{11}$ The following anecdote, related from an anonymous manuscript writer sheds more light on the hidden proverbs in the Glorious Qur'ān. It reads thus:

Abul-Abbas Ahmad bn Ibrahim al-Razi spoke to us: He said: Abul-Qāsim al-Hasan bn Muhammad al-Nisabūrī spoke to us. He said: I heard my father saying: I asked al-Hasan bn al-Fadl, and said to him: You are fond of extracting proverbs of the Arabs as well as that of the non-Arabs from the Glorious Qur'ān. Could you find in the Qur'ān (the Arabic proverb) خير الأمور الوسط "The best of things is the middle". He said: Of course, there are in four instances. First, in Allah, the Almighty's statement:

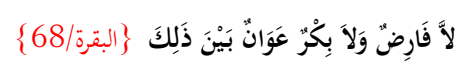

The heifer should be neither old nor too young, but of middling age. (Qur'ān 2:68). 
Secondly, in Almighty Allah's statement on charitable gift:

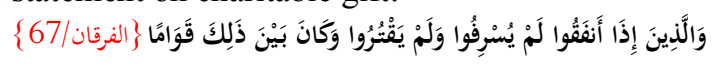

Those who, when they spend, are not extravagant and are not niggardly, but hold a just (balance) between those (extremes).

(Qur'ān 25:67).

Thirdly, in Allah's commandment to His prophet (PBOH) and his community on Salāt (five daily prayers):

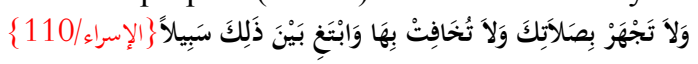

Neither speak thy prayer aloud, nor speak it in a low tone, but seek a middle course between. (Qur'ān 17:110).

Fourthly, His statement directed to His Prophet (PBOH):

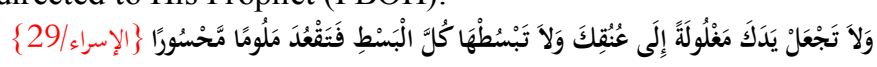

Make not thy hand tied (Like a niggard's) to thy neck, nor stretch it forth to its utmost reach, so that thou become blameworthy and destitute. (Qur'ān 17:29).

This same man was said to have been asked of about other thirty-five Arabic proverbs and he was able to provide their parallels in the Glorious Qur'ān. ${ }^{12}$

Below are some examples to explicate further:

1.

He who digs a pit for his brother shall himself fall into it.

Whereas the Almighty Allah says in the Glorious Qur'ān:

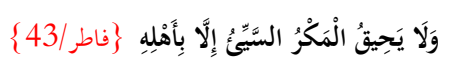

But the plotting of Evil will hem in only the authors thereof.

(Qur'ān 35:43).

2.

$$
\text { سِيَمَاؤهُمْ فِي وُجْوَهِهِ }
$$

"The face is the index of the heart".

While Allah says in the Glorious Qur'ān:

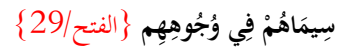

On their faces are their marks.

(Qur'ān 48:29).

3.

$$
\text { أدنى مِنْ حَبْل الْورِيدِ }
$$

"Closer than the carotid artery"

While Allah says in the Glorious Qur'ān:

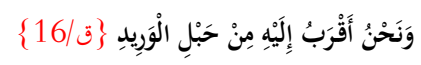

For We are nearer to him than (his) jugular vein (Qur'ān 50: 16)

4.

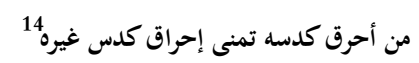

He who sets ablaze his own business shall wish same for others.

While Allah says in the Glorious Qur'ān: 


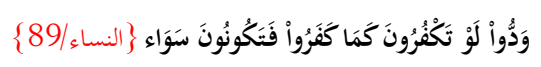

They but wish that ye reject Faith, as they do, and thus be on the same footing (as they)

(Qur'ān 4: 89)

5.

$$
\text { لا لأؤخر عمل اليوم إلى الغد }
$$

Never put off till tomorrow what may be done today.

While Allah says in the Glorious Qur'ān:

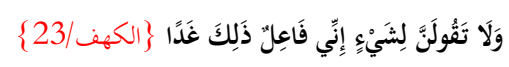

Nor say of anything "I shall be sure to do so and so tomorrow".

(Qur'ān 18:23).

6.

$$
\text { إِنَّ بعد الْعُسْرِ ِيُسرًا }
$$

"After a storm comes a calm".

While Allah says in the Glorious Qur'ān:

$$
\text { سيجعل الله بعد عُسْرِ يُسرًاً }
$$

Allah will soon grant relief.

(Qur'ān 65: 7)

7.

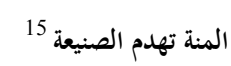

Reminder of generosity destroys good deed.

While Allah says in the Glorious Qur'ān:

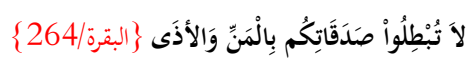

Cancel not your charity by reminders of your generosity or by injury.

(Qur'ān 2: 264)

8.

$$
16 \text { يُقَلِّبُ كَفَيْْهِ }
$$

He is twisting and turning his hands.

(It is said of someone who is regretting over the bygones).

While Allah says in the Glorious Qur'ān:

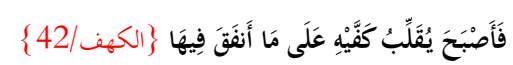

And he remained twisting and turning his hands over what he had spent on his property.

(Qur'ān 18: 42).

\section{The Hadith as a Source of Arabic Proverbs}

Another rich source of Arabic proverbs after the Glorious Qur'ān is the Hadìth, the public and private sayings of the prophet which were handed down orally from generation to generation and thereafter compiled and recorded in books. At a point in time, it was estimated that about 600,000 had been attributed to the prophet but when the six traditionists - al-Bukhārī, Muslim, Abū Dāud, Ibn Majah, al-Tirmidhī, and al-Nisā̄̄ themselves on the task of authenticating these ahädith, a number of them could not be confirmed and thus discredited.

These men also wrote books, the most famous of which is Sahīh al-Bukhārī. This book, a collection of 7,275 authentic saying of the prophet, has been described by some Muslim jurists as "the most reliable book after the Book of God..." "17 Besides, Sahīh al-Bukhārī and Sahīh Muslim have also served as rich reference 
points for later researchers on Arabic proverbs in the prophetic sayings. Four hundred and thirty-two of Fayyād's one thousand, three hundred and sixty-eight proverbs credited to the prophet were got from both Sahīh al-Bukhārī and Sahīh Muslim. ${ }^{18}$

Some proverbial expressions of the prophet are so tied to the stories and tales behind them, and without which they cannot be properly understood. Among these are the following:

The first one goes thus:

$$
\text { سبقك بها عكاشة19 }
$$

'Ukāshah has preceded you into it.

This saying is a factual statement in which 'Ukāshah has been mentioned as the one who precedes somebody else. Yet we neither have knowledge of him who precedes other nor the one who is being preceded. Also, we have no knowledge of the ground on which one has preceded the other. This necessitates the stories and tales behind such proverbs in order to give room for proper discernment, like the case in some proverbs of the pre-Islamic era.

History has it that, the messenger of God (P.B.O.H) said one day while he was in the company of his companions:

$$
\text { يدخل الجنة من أميع سبعون ألفا بغير حساب. وهم الذين لايسترقون ولايتطيون ولايكتوون وعلى ربهم يتوكلون. }
$$

Seventy thousand (people) among my followers shall gain entrance into the paradise without reckoning. These are they who do not eavesdrop and being pessimistic in nature. They do not burn their skins and rely solely on their Lord.

'Ukāshah bn Muhsin said:

$$
\text { أمنهم ألا يا رسول الله؟ }
$$

"Oh messenger of God, am I part of them?"

He said: "نعم" "Yes".

Then another man (from the congregation) said:

$$
\text { أمنهم ألا يا رسول الله؟ }
$$

Oh messenger of God, am I among them?

The Prophet (P.B.O.H) said:

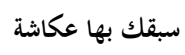

"Ukāshah has preceded you into it".

The statement thus passed into proverb and it is being used proverbially for whoever has been preceded into something.

Another prophetic saying goes thus:

$$
\text { لكن حمزة لا بواكي له }
$$

Indeed, Hamzah has no wailers on his behalf.

The history has it that the prophet said thus on his return from the battle of $H \bar{u} d$ when he saw women of the $A n s \bar{a} r^{21}$ wailing on their martyred relations and found no one to wail for Hamzah, who on account of the Holy prophet (P.B.O.H) deserved wailing more than any other person for he was the chief of the martyrs. His sayings لكن حمزة لا بواكي له (As for Hamzah, there are no wailers) thus passed on to proverb for whoever best deserves help but finds no helper.

Similarly, in another proverb which emanated from a prophetic tradition, we find the following:

$$
\text { اعقل وتوكل22 }
$$

Tie (your camel) and rely (on God)

This proverb is said to have originated in the prophet's conversation with a man amongst his companions who paid him a courtesy visit and left his camel wandering all about. He said to the prophet: 


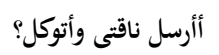

Should I leave my camel untied and (fervently) rely on God?

The prophet responded saying:

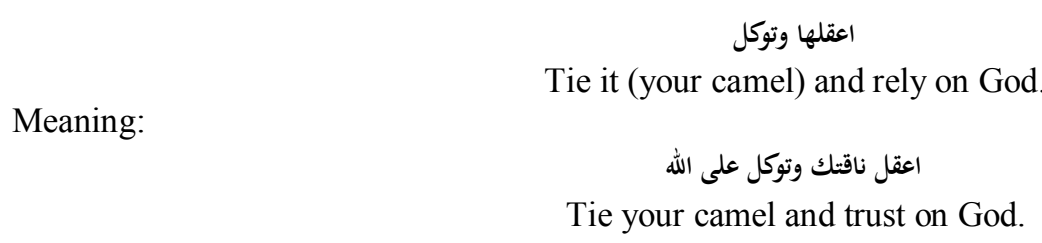

Without the attached information on this incidence, no one, even a magician can neither decipher the subject nor object of this statement.

\section{Arabic Literature as a Source of Arabic Proverbs}

Arabic literature, both prose and poetry is also the rich source of classical Arabic proverbs. The most widely quoted Arab poets are Zuhayr b. Abī Sulmā and Abū al-Tayyib al-Mutanabbī. The former was a wise man of pre-Islamic era who summed up the logic and wisdom of his time in beautiful verses which are still quoted till date was said to have spent one full year in composing some of his poems, while the latter was a prominent poet of the Abbasid era (750-1258C.E) who, in the words of Rayess Fuād, 'like Shakesphare achieved a peak in his achievements unequalled by anyone since'. ${ }^{23}$ Another prominent Arab to whom many proverbs are credited is Aktham b. Sayfi, a prose writer of pre-Islamic era. ${ }^{24}$

In the view of non-Arabs, particularly the Westerners, the subtlety of many Arab quotations is lost. This is due to their unfamiliarity with the background which is very essential to comprehension, at times because the sayings, like some wines, simply don't travel. Among such sayings are the following:

1.

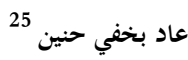

"He returned with Hunayn's slippers".

That is, "he failed on his mission" or "he accomplished nothing".

History has it that, there was a cobbler whose name was Hunayn. One day, he was annoyed by a tightfisted Bedouin Arab who bargained all day for a pair of slippers but refused to buy them. Hunayn then decided to get back at him. He rode out ahead of the Bedouin, placed one of the slippers on the road where the Bedouin was sure to pass and the other slipper further on.

When the Bedouin passed by and saw the first slipper, he soliloquizes, "This is exactly like the one I wanted to buy from Hunayn. It is too bad the other slipper is not with it". Seeing that he could make no use of it, he left it in its place and moved on. Before long, he reached the other slipper and decided to go back and get the first one too. He was in such hurry, however, that he left his camel and gear behind, and Hunayn took the camel and ran away, leaving the Bedouin to return to his tribe with nothing but his (Hunayn's) slippers.

This is a simple story, but many non-Arabs, particularly the West, looking for a clever twist, or a pointed moral, find it flat, whereas in Arabic it is delightful.

$$
\text { وافق شن طبق }
$$

Shann suited Tabaqah

History also has it according to a narration from al-Sharqī bn al-Qutāmī: there was a clever man amongst the Arabs called shann. He resolved that he would tour round the cities and villages to find somebody like him to marry as a wife. He was once roaming about when he met a man. Shann asked the man where he was heading to. The man mentioned a place which tallied with the village Shann was also heading to, so they became companions on their journey.

On the way, Shann said to him:

$$
\text { أتحملنى أم أحملك؟ }
$$

"Would you bear me or I should bear you?"

The man said:

Oh you ignorant: I am riding and you are also on a ride, how would I bear you or how would you bear me? 
Shann kept silent as they continued (on their journey), until they got near the village and found themselves beside an harvested plantation. Shann said to him:

$$
\text { أترى هذا الزرع أكل أم لا؟ }
$$

"You perceive this plantation eaten or not?"

The man answered:

Oh ignorant, you see a harvested plantation and you are still asking whether it has been eaten or not?

Shann still remained silent until they entered the village and met a funeral procession. Shann said:

$$
\text { أترى صاحب هذا النعش حيا أم لا؟ }
$$

"You perceive the inhabitant of this coffin alive or dead?"

The man said:

I have not seen somebody steeper in ignorance than you. You see a funeral procession and you are asking whether the occupant of the coffin is dead or alive?

Shann remained silent again but opted to separate with him but the man declined, as he wanted him to accompany him to his house and he (shann) followed him. That man had a daughter called Tabaqah, when her father entered, she inquired him about his guest. He (the father) narrated his encounters with him and complained to her of his ignorance. He told her precisely some of his sayings. She said:

Oh father, this is not an ignoramus.

As for his saying:

$$
\text { أتحملنى أم أحملك؟ }
$$

"Would you bear me or I should bear you?"

He meant:

$$
\text { أتحدثنى أم أحدثك؟ }
$$

"Would you engage me in a conversation or I should engage you during the course of our journey?

As for his saying:

$$
\text { أترى هذا الزرع أكل أم لا؟ }
$$

"You see this plantation eaten or not?

He meant:

$$
\text { أباعه أهله فأكلوا ثمنه أم لا؟ }
$$

Did its owner sell it and exhaust its price or not?

As for his saying on al-Janāzah - الجنازة - (funeral procession), he meant: ل Whether he has left offspring who will keep him alive in remembrance or not?

The man thereafter went out (of his daughter) and stood with Shann and held conversation with him for about an hour, and said to him:

$$
\text { أتحب أن أفسر لك ما سألني عنه؟ }
$$

Do you wish that I explain to you all you have asked me?

He (Shann) said: yes and he (the man) explained them. Then Shann said:

$$
\text { ما هذا من كلامك }
$$

"These are not your words". Inform me the owner (of these words).

He said: 'A daughter of mine'. He then gave her to him in marriage and he (Shann) took her to his relations. When they (the relations) saw both of them, they said:

$$
\text { وافق شن طبقة }
$$

"Shann suited Tabaqah".

That is, they are of a kind. They really match. Thus it passed into proverb. It is being used to describe two people who marry or are closely associated with each other. 
3.

$$
27 \text { مثل بقرة جحا }
$$

Like Jihā's cow.

History has it that, there was a proverbial man called Jihā. He slaughtered his cow, sold the meat, and received his pay. After a while, he again demanded pay from each purchaser and received it. He kept doing this till he died. This saying is used of an affair which is long drawn out.

These stories and the likes however, are in a minority. Most Arabic proverbs instantly ring a bell and easily digested without further ado.

\section{Conclusion}

The paper reveals that the rich source of Arabic proverbs is the Glorious Qur'ān. The proverbial expressions in the Qur'ān are of two kinds, the apparent and the hidden. The former is identified as the kind in which the word mathal, (proverb) is clearly stated, while in the latter, the word mathal is not mentioned at all and to some extents, makes it obscure. Nevertheless, it has a sort of correlation with Arabic proverbs or those of the non-Arabs or even the ones that have universal application. By implication, the hidden proverbs are deduced from the popular ones and are mostly identified by their meaning, not by mere wordings. Hence, there is no limit to the amount of hidden proverbs that could be found in the Qur'ān. Other sources of Arabic proverbs include hadith, the public and private sayings of the Holy Prophet Muhammad, and the gamut of Arabic literature, both prose and poetry.

\section{References}

[1]. F. Rayess, The cream of wisdom, Aramco World Magazine. Jan./Feb. (New York, 1969) 23.

[2]. F. Rayess, The cream of wisdom, (1969). See also: W.G. Smith, The Oxford Dictionary of English Proverbs. (Oxford: The Clarendon Press, 1935) 678pp.

[3]. F. Rayess, The cream of wisdom, (1969) 23.

[4]. F. Rayess, The cream of wisdom, (1969) 23.

[5]. Fuad Rayess was the general supervisor of the Arabic Press and Publications Division of the Aramco Public Relation Department in Dhahran, Saudi Arabia.

[6]. M.J. Al-Fayyād, Al-'Amthāl fì al-Hadīth al-Nabawī al-Sharīf. $1^{\text {st }}$ ed., (Riyādh: Maktabah al-Mu'ayad, 1993$) 69$.

[7]. M.J. Al-Fayyād, Al-'Amthāl fì al-Hadīth al-Nabawì al-Sharīf, (1993) 70.

[8]. M.J. Al-Fayyād, Al- 'Amthāl fì al-Hadīth al-Nabawì al-Sharīf, (1993) 70.

[9]. M.J. Al-Fayyād, Al-'Amthāl fì al-Hadīth al-Nabaw̄̄ al-Sharīf, (1993) 70. See also: B.M.A. Al-Zarkazi, Al-Burhan fi Ulūm alQur'an. Vol. 1, I. Abu-Fadl ed. (Cairo: Matbaah Isa al-Hilbi, 1957) 486-487.

[10]. See B.M.A. Al-Zarkazi, Al-Burhān fi Ulumil-Qur'ān. Vol. 1. (1957) 486; J.L. Al-Suyutī, Al-'Itiqan fi Ulumil-Qur'ān. $3^{\text {rd }}$ ed. vol. 2. (Cairo: Maktabatu Mustapha Al-Hilbi, 1951) 132; A. Al-Hashim, Jawairul-Adab. Vol. 1. (Cairo: Tabi'atul-Sa'adah, 1962) 288. Cited in M.J. Al-Fayyād, Al-Amthāl fil-Qur'ānil-Karīm. $2^{\text {nd }}$ ed. (Riyadh: International Islamic Publishing House- I.I.P.H, 1995) 201-203 [originally published in Baghdad: Al-Shu 'un al-Thaqafiyyah al-'Ammah, 1988) II+455.

[11]. H. Muhammad, Al-Tajwāl fì Kutubil-'Amthāl, (Beirut: Darul-Kutubil-'Ilmiyyah, 2002) 19.

[12]. M.J. Al-Fayyād, Al-Amthāl fil-Qur'ānil-Karìm, (1995) 203. Cf. H. Muhammad, (Al-Tajwāl fì Kutubil-'Amthāl, 2002) 19-20.

[13]. M.J. Al-Fayyād, Al-Amthāl fil-Qur'ānil-Karīm, (1995) 203.

[14]. M.J. Al-Fayyād, Al-Amthāl fil-Qur'ānil-Karìm, (1995) 203.

[15]. A.M. Al- Maydān̄̄, Majma ul-Amthāl 2. (Proverb 3912). Muhammad, M. A. ed. (n.p: Matb'ah al-Sunnah al-Muhtiyyah, 1955) 287.

[16]. A.M. Al-Maydān̄, Majma 'ul-Amthāl 2. (Proverb 4747), (1955) 426

[17]. F. Rayess, The Cream of Wisdom. Aramco World Magazine. Jan./Feb. (New York: 1969) 23.

[18]. M.J. Al-Fayyād, Al- 'Amthāl fì al-Hadīth al-Nabawī al-Sharīf, (1993) 1-580.

[19]. M.J. Al-Fayyād, Al- 'Amthāl fì al-Hadīth al-Nabawī al-Sharīf, (1993) 131-132.

[20]. M.J. Al-Fayyād, Al- 'Amthāl fì al-Hadīth al-Nabawì al-Sharīf, (1993) 132.

[21]. The term Ansār was and is still employed for the people of Madinah who accommodated the Holy Prophet and his followers when they left Makkah for Madinah after they faced series of persecutions in the hands of the pagans of Makkah. Ansār is being translated as "the helpers of the Holy Prophet".

[22]. A.M. Al-Maydān̄, Majma'ul-Amthāl 2, (Proverb 2473), (1955) 26-27.

[23]. F. Rayess, The Cream of Wisdom. Aramco World Magazine, (New York: Arabian Amercan Oil Company, 1969), 23 A. AlAskandari, et.al. Al-Mufassal fì Ta'rikh al-Adab al-Arabī li al-Madāris al-Thanāwiyyah. 1, (n.p, n.d) 90.

[24]. H. Muhammad, Al-Tajwāl fì Kutubi al-'Amthāl, (Beirut: Dār al-Kutub al-'Ilmiyyah, 2002) 36-37. cf. proverb 1568 in A.M. AlMaydān̄̄, Majma' al-Amthāl. vol. 1, (1955) 366 (رجع بخفي حنين).

[25]. H. Muhammad, Al-Tajwāl fĩ Kutubi al-'Amthāl, (2002) 35-36.

[26]. J.R. Jewett, Arabic proverbs and proverbial phrases, Collected, Translated and Annotated. Journal of American Oriental Studies. (n.p: American Oriental Studies, 1893) 47. 